\title{
?1
}

TI 2018-077/VIII

Tinbergen Institute Discussion Paper

\section{Airfares with codeshares: (why) are consumers willing to pay more for products of foreign firms with a domestic partner?}

Revision: February 28, 2021

Gerben de Jong ${ }^{1,2}$

Christiaan Behrens ${ }^{1,2}$

Hester van Herk ${ }^{1}$

Erik (E.T.) Verhoef ${ }^{1}$ 
Tinbergen Institute is the graduate school and research institute in economics of Erasmus University Rotterdam, the University of Amsterdam and Vrije Universiteit Amsterdam.

Contact: discussionpapers@tinbergen.nl

More TI discussion papers can be downloaded at https://www.tinbergen.nl

Tinbergen Institute has two locations:

Tinbergen Institute Amsterdam

Gustav Mahlerplein 117

1082 MS Amsterdam

The Netherlands

Tel.: +31(0)205984580

Tinbergen Institute Rotterdam

Burg. Oudlaan 50

3062 PA Rotterdam

The Netherlands

Tel.: +31(0)10408 8900 


\title{
Airfares with codeshares: (why) are consumers willing to pay more for products of foreign firms with a domestic partner?
}

\author{
Gerben de Jong*1, 2, Christiaan Behrens ${ }^{1,2}$, Hester van Herk $^{1}$, and Erik Verhoef ${ }^{1,3}$ \\ ${ }^{1}$ School of Business and Economics, Vrije Universiteit Amsterdam, De Boelelaan 1105, $1081 \mathrm{HV}$ \\ Amsterdam, Netherlands \\ ${ }^{2}$ SEO Amsterdam Economics, Roeterstraat 29, 1018 WB Amsterdam, Netherlands \\ ${ }^{3}$ Tinbergen Institute, Gustav Mahlerplein 117, 1082 MS Amsterdam, Netherlands
}

February 28, 2021

\begin{abstract}
Economic globalization has spurred the growth of international cooperation between companies. This paper analyzes partnerships between foreign and domestic firms as a source of signaling advantages. When partnerships affect the products offered, it is not possible to isolate this signaling impact. Virtual codesharing is an important type of marketing partnership in aviation that does not change the product and hence provides the opportunity to identify the direct impact of partnerships on consumer valuation of the partnered products. Roughly 75 per cent of the flights in trans-Atlantic and Pacific markets involves codesharing. Typically, the consumer buys the ticket with the domestic airline, while a foreign airline operates the flight. Analyzing individual-level choice data from a representative panel of Australian air travelers, we find that the average consumer is willing to a pay a premium between 4 and $5.5 \%$ of the ticket price when a flight by a foreign carrier is codeshared with the national carrier Qantas. When flying to a less familiar destination, risk averse consumers are willing to pay a premium about two times higher than non-risk averse consumers, suggesting that partnerships have a strong impact on consumer valuation through quality signaling.
\end{abstract}

JEL classifications: L15, L93, M31.

Keywords: airline codesharing, marketing partnerships, consumer choice behavior, quality signaling, aviation industry.

*E-mail address corresponding author: g2.de.jong@vu.nl (G. de Jong). 


\section{Introduction}

Partnerships in which two brands are visibly linked through joint marketing are present in many markets (Rao and Ruekert, 1994). Firms may enter into such partnerships to benefit from brand spillovers, extend product offerings and signal unobserved product quality (Rao et al., 1999; Choi and Jeon, 2007; Johnson, 2013; Choi and Peitz, 2018). Other times joint marketing is part of more general forms of inter-firm cooperation. Following the globalization of markets, partnerships between firms in geographically separate and culturally different countries intensified. A clear example of this is found in the airline industry where cooperation between international carriers has surged in recent decades (see, e.g., Brueckner, 2001, 2003; Bilotkach and Huschelrath, 2011; Gayle and Thomas, 2016; Gayle and Xie, 2019)

In this study we empirically analyze the signaling benefit accrued by foreign firms that partner with a firm from the consumers' domestic country. To this end, we turn to the international aviation industry and consider a specific type of marketing partnership between airlines, virtual codesharing, which enables us to empirically identify the impact of partnering with a domestic carrier through quality signaling and subjective perception of quality, independent of the partnership's impact on real product attributes.

While important to theory and practice, the signaling impact of foreign-domestic cooperation has not been assessed before, neither in aviation nor for comparable partnerships in other markets. The likely reason for this is that in most markets, it is not feasible to identify the direct impact of the cooperation on consumer purchasing behavior. As partnerships often also change product offerings, for instance by integrating two products into one joint offering, the effects of such partnerships may not only reflect the impact of the cooperation itself. The international aviation industry does enable us to isolate this impact, as virtual codesharing provides exactly the same product - a flight produced by a foreign airline - but offered via a domestic airline.

The individual-level choice data collected for this study show that consumers are willing to pay significant premiums for flights by foreign carriers that are offered through their national carrier via codesharing. This premium is higher for risk-averse consumers, especially when flying on less common destination markets, suggesting that consumer valuation is increased through quality signaling. Given that the average premium varies between 4 and $5.5 \%$ of the ticket price (i.e., 68 to 96 AUD on a 1800 AUD ticket), the signaling effect uncovered in this paper represents an important factor to take into account in policy evaluations of international (airline) cooperation. 


\subsection{Context and literature}

In a codesharing agreement one carrier ('the marketing carrier') is allowed to market and sell seats on a flight operated by another carrier ('the operating carrier'). Airlines use codesharing to extend the scope of their route networks, exploit economies of density, and establish a presence in foreign markets (e.g., Brueckner, 2001, 2003; Ito and Lee, 2007; Brueckner et al., 2011; Adler and Hanany, 2016). As codesharing agreements are a form of horizontal cooperation they have been analyzed extensively for their potential to reduce competition (e.g., Armantier and Richard, 2008; Gayle, 2007; Brueckner et al., 2011).

A concise analysis of air travel data from the Official Airline Guide (OAG) illustrates the omnipresence of codesharing in the international airline industry. In 2018, about 75 percent of all direct (non-stop) and indirect flights offered between the United States and Australia involved at least one codeshare segment, and similar numbers apply to flights between the United States and Europe. Codesharing is done with partners from all over the world and codeshare partners may be from countries that are geographically and culturally close or distant; for instance, American Airlines codeshares with British Airways, Royal Air Maroc and Malaysia Airlines, among many others.

Traditionally, codesharing was used to provide seamless travel on interline routes that required passengers to switch carrier during the trip. Nowadays the majority of codesharing applies to online routes that are operated by a single carrier, a practice that is known as virtual codesharing (Ito and Lee, 2007). Under virtual codesharing the marketing carrier is no longer involved in operating the flight and, hence, a codeshared and non-codeshared flight operated by the same airline represent essentially the same product. In fact, for many flights some of the seats are sold directly by the carrier operating the flight (pure online products), while other seats - on that same flight - are sold by codesharing partners that are not involved in operating the flight (virtual codeshare products).

Next to the codesharing literature, our study builds on a body of evidence in economics and marketing showing that consumer demand patterns are positively biased towards domestic goods and services (e.g., Verlegh and Steenkamp, 1999; Cosar et al., 2018; de Jong et al., 2019). These studies demonstrate that country of origin is an important determinant of a consumer's attitude towards a product and, especially, that consumers often prefer domestic over foreign alternatives. We combine these observations to the theory of co-branding as a way to leverage another firm's reputation (e.g., Choi and Jeon, 2007) and apply this to the context of codesharing. As such, consumers' willingness to pay for an international flight may depend on the country of origin of the marketing partner, which may be especially relevant if this partner is from their home country. 


\subsection{Study setup and findings}

Our study analyzes consumer choice data on international route markets where flights are offered as pure online as well as virtual codeshared products, focusing on two markets from Australia to North and South America as examples thereof. Unlike previous studies on codesharing, we use individuallevel data obtained from a stated preference experiment that resembles the booking environment that air travel consumer face when purchasing their tickets online. ${ }^{1}$ A clear benefit of this experimental setup is that it not only allows us to derive consumer preferences for various codeshare products, but also helps understanding some of the behavioral mechanisms underlying the consumer choice process in the many international aviation markets where such products are jointly available - something that would not be possible with pure revealed preference data.

Using a discrete choice framework, we find that willingness-to-pay for flights operated by alien carriers increases substantially once these flights are offered as virtual codeshare products. This effect is particularly pronounced for the virtual codeshare products that are offered through the consumers' own national carrier and bridges a substantial part of the premium that the national carrier can command on its own pure online products. For instance, in the North-American destination market, the premium for virtual codeshare products offered through the Australian national carrier, Qantas, is equal to about $4 \%$ of the ticket price, while Qantas obtains a premium of $5 \%$ on its own pure online products (all relative to the pure online products of alien carriers).

Importantly, standard explanations for higher willingness-to-pay due to codesharing as mentioned in the literature, i.e., more convenience and better opportunities to accumulate and redeem frequent flier miles, are ruled out by our experimental design. ${ }^{2}$ We therefore explore two alternative explanations of the willingness-to-pay for codeshared products, both of which deal with incomplete information on the part of the consumer. The first posits that consumers may not be fully informed about the meaning of codesharing. ${ }^{3}$ The second holds that consumers may be uncertain about the

\footnotetext{
${ }^{1}$ Air travel consumers are known to be highly skilled in trading off ticket fares against attributes of products offered in such online environments (see, e.g., Mantin and Rubin, 2016). This provides confidence in respondents' abilities to deal with the choice tasks they face and their inclination to treat them as realistic.

${ }^{2}$ Convenience benefits such as coordination of flight schedules, check-in and luggage handling, do not arise on direct routes which we study here and respondents are instructed that they cannot earn or spend frequent flier miles on any of the available flights during the experiment. With respect to the latter, an additional robustness check in which we include covariates for frequent flier program membership does not alter our findings, nor do we find systematic differences in the willingness-to-pay for codeshared products among carriers that have integrated frequent flier programs versus carriers whose programs are not integrated.

${ }^{3}$ This idea is often voiced in popular press, as well as documented in academic literature (Goh and Uncles, 2003).
} 
quality of alien carriers and perceive codesharing by familiar carriers (e.g., their own national carrier) as a signal to reduce uncertainty and risk.

To explore these explanations, we ask respondents for their definition of codesharing and exploit the availability of individual-level indicators of risk attitude in our data. ${ }^{4}$ While we find that there indeed are widespread misconceptions about codesharing, these misconceptions do not account for the premium on codeshared flights. Rather, causality seems to run the other way: consumers who have a strong preference for flying with a particular carrier appear to have a stronger incentive to be informed about codesharing. However, in line with the signaling explanation, we find that more risk-averse consumers are willing to pay higher premiums for flights codeshared by their own national carrier than less risk-averse consumers. Moreover, this effect particularly occurs in the South-American destination market, presumably reflecting the higher levels of consumer uncertainty about the quality of the alien carriers in this market.

\subsection{Contributions}

This paper contributes to a vast literature on the impact of codesharing agreements. We are one of the first to look into codesharing's signaling effects. Our work is most closely related to Gayle (2007), who studied whether passengers perceive a distinction between an airline's virtual codeshare products and it's pure online products in the US domestic market. Contrary to his findings in the domestic context, we show that international consumers value an otherwise identical flight differently once it is codeshared - in particular if their own national carrier is involved in the codeshare agreement. This has important implications for policy analyzes and evaluations of international airline partnerships, where increases in willingness-to-pay for partnered products is usually taken as evidence of increased product quality. Ignoring that willingness-to-pay increases may also arise through signaling could lead to overestimation of the quality benefits of new and existing codeshare partnerships.

Our findings are also complementary to the literature on consumers' domestic country bias mentioned earlier. By analyzing airfares in markets with international partnerships, we find that this bias spills over to foreign partners that engage in horizontal partnerships with domestic suppliers. As such, a large part of the domestic bias may be overcome by selling through a domestic partner.

\footnotetext{
${ }^{4}$ As one might be concerned that codeshare definitions and risk attitude are endogenous with respect to airline choice behavior, we employ a hybrid panel mixed logit approach, which addresses measurement bias-related endogeneity and alleviates concerns over omitted variables (see, e.g., Ashok et al., 2002; Ben-Akiva et al., 2002; Vij and Walker, 2016; Czajkowski et al., 2017).
} 
While the aviation context allows us to perfectly isolate the impact of international partnerships, the insights and implications are likely to carry over to other markets where competition is international and (unobserved) quality differences, and signals on these, are relevant for consumers. Examples could be hotel chains (with franchising), car rentals, fast-food outlets, internet platforms, etc. Our findings thereby also add to the body of research on the effects of partnerships on consumer attitudes and purchase intentions, which has not yet explicitly considered international partnerships (e.g., Rao et al., 1999; Simonin and Ruth, 1998; Choi and Jeon, 2007; van der Lans et al., 2014).

This paper proceeds as follows. Section 2 presents the experiment and the data. Section 3 describes the econometric approach. Section 4 discusses the findings. Section 5 concludes.

\section{Experimental setup and data}

\subsection{Stated preference experiment}

To examine consumer choices between pure online and virtual codeshare products, we use data collected through a stated preference experiment conducted in Australia. The experiment covers two long-haul non-stop destination markets from Australia to Santiago, Chile (Santiago International Airport, SCL), and to San Francisco, United States (San Francisco International Airport, SFO). From the Australian consumers' point of view, San Francisco represents a more familiar destination than Chile. ${ }^{5}$ The process and presentation of the survey is similar to the way travel agency websites operate. Respondents first select the preferred origin airport for their trip and, subsequently, are presented with a number of flight alternatives (i.e., four in each scenario) that are characterized by the marketing-operating carrier combination of the flight, the travel time and the ticket fare. ${ }^{6}$ Each respondent was presented with six of such choice scenarios per destination market.

Table 1 shows the levels of each flight characteristic. The most important characteristic for the purpose of our analysis is the marketing-operating carrier combination. This defines the type of flight product; whether it is a pure online or virtual codeshare product, and which carriers

\footnotetext{
${ }^{5}$ For example, the actual number of seats offered on routes from Australia to North America is about ten times larger than to South America: 2 vs 0.2 million seats in 2017 (Australian Bureau of Infrastructure Transport and Regional Economics, 2018). Moreover, it is likely that Australian consumers perceive South America as a more risky destination due to greater cultural, economic and political distance with their home country (Giannetti and Yafeh, 2012).

${ }^{6}$ The preferred origin airports a respondent could choose from are: Sydney Airport (SYD), Melbourne Airport (MEL), Brisbane Airport (BNE), Adelaide Airport (ADL), Gold Coast Airport (OOL), Cairns Airport (CNS) and Canberra Airport (CBR). These airports cover the main Australian airports used for intercontinental flights.
} 
Table 1: Flight characteristics and levels

\begin{tabular}{lll}
\hline \hline Characteristics & Destination market & Levels \\
\hline Marketing-operating carriers & Santiago & QF/QF, NZ/NZ, LA/QF, AV/QF, LA/NZ, \\
& & AV/NZ, LA/LA, AV/AV, AR/AR \\
& San Francisco & QF/QF, NZ/NZ, AA/QF, UA/QF, AA/NZ, \\
& & UA/NZ, AA/AA, UA/UA, DL/DL \\
Ticket fare & Both & $1700-1880$ AUD (steps of 20 AUD) \\
Travel time & Both & $13 \mathrm{~h} 30-15 \mathrm{~h} 00$ (steps of 15min.) \\
\hline
\end{tabular}

Note(s): Carrier designator codes: QF - Qantas; NZ - Air New Zealand; LA - LATAM; AV - Avianca; AR - Aerolineas Argentinas; AA - American Airlines; UA - United Airlines; DL - Delta Air Lines.

Table 2: Typology of flight products

\begin{tabular}{llll}
\hline \hline & & Santiago & $\begin{array}{l}\text { San Francisco } \\
\text { flight products }\end{array}$ \\
\hline Plight product type & Notation & QF/QF & QF/QF \\
Pure online flights neighboring national carrier & $\mathrm{QF} / \mathrm{QF}$ & $\mathrm{NZ} / \mathrm{NZ}$ & $\mathrm{NZ} / \mathrm{NZ}$ \\
Codeshare flights own national carrier & $* / \mathrm{QF}$ & $\mathrm{LA} / \mathrm{QF}, \mathrm{AV} / \mathrm{QF}$ & $\mathrm{AA} / \mathrm{QF}, \mathrm{UA} / \mathrm{QF}$ \\
Codeshare flights neighboring national carrier & $* / \mathrm{NZ}$ & $\mathrm{LA} / \mathrm{NZ}, \mathrm{AV} / \mathrm{NZ}$ & $\mathrm{AA} / \mathrm{NZ}, \mathrm{UA} / \mathrm{NZ}$ \\
Pure online flights alien carriers & $* / *$ & $\mathrm{LA} / \mathrm{LA}, \mathrm{AV} / \mathrm{AV}$, & $\mathrm{AA} / \mathrm{AA}, \mathrm{UA} / \mathrm{UA}$, \\
& & $\mathrm{AR} / \mathrm{AR}$ & $\mathrm{DL} / \mathrm{DL}$ \\
\hline
\end{tabular}

Note(s): See footnote below Table 1 for carrier designator codes.

are involved in operating and marketing the flight. Throughout this paper we simply refer to these marketing-operating carrier combinations as 'flight products'. We describe each flight product using the convention operating carrier code/marketing carrier code from Ito and Lee (2007). ${ }^{7}$ Each destination market involves nine distinct flight products, which cover five flight product types that are summarized in Table 2.

For the other two flight characteristics, travel time and ticket fare, we choose levels that are typically observed in the considered route markets. All flights during the experiment are presented as non-stop flights. As such it is unlikely that convenience benefits of codesharing on connecting routes, e.g. coordination of flight schedules, check-in and luggage handling, would lead to differences in valuations of an airline's pure online or virtual codeshare products. ${ }^{8}$ Our focus on non-stop flights

\footnotetext{
${ }^{7}$ For example, QF/QF denotes a pure-online flight by Qantas, whereas AA/QF denotes a flight operated by American Airlines and codeshared by Qantas.

${ }^{8}$ To some consumers, aspects of the pre- and post-flight experience may still be somewhat different (e.g., a consumer may find it convenient to cancel a flight through the codesharing partner's website), but given the magnitudes of the price premiums we identify in this paper, it seems very unlikely that this could make up most, or even a substantial share, of consumers' willingness-to-pay for codesharing.
} 
has the further benefit of avoiding unrealistic combinations of travel times and stopovers. Moreover, respondents are informed that they cannot earn or spend frequent flier miles on any of the available flights. Consequently, the scenarios offer a realistic yet simple trade-off between flight product type and time or monetary costs (for an example of a choice scenario, see Appendix A).

A statistically efficient experimental design was generated using Sawtooth's complete enumeration method. This method results in a heterogeneous design, meaning that there are multiple versions of the design to which respondents are randomly allocated (see Chrzan and Orme, 2000, for technical details about the design). This type of design leads to substantial gains in efficiency as compared to homogeneous designs and avoids order effects (Sándor and Wedel, 2005; Liu and Tang, 2015). Before fielding the experiment, we conducted two pilot tests using samples of Dutch undergraduate students $\left(n_{1}=225\right.$ and $\left.n_{2}=204\right) .{ }^{9}$ These pilot tests confirmed that respondents could easily relate to the choice scenarios and that the experimental design results in data that allows for efficient estimation of the effects of interest.

\subsection{Codeshare (mis)conceptions and risk attitudes}

In addition to the stated preference data, we collect information on respondents' (mis)conceptions of codesharing and their risk attitude. Codeshare (mis)conceptions were captured by a multiplechoice question at the end of the experiment asking respondents to select the correct definition of codesharing. The question referred back to the experiment as follows: "In the air travel choice experiment, it sometimes said in smaller print that a flight offered by airline A (the one shown in the logo) was operated by airline B. What do you think is meant by this?" The answer options given were: "Airlines A and B are not formally merged but known under the same airline code"; "Airlines A and B sell seats for a flight that is made in an aircraft and with a crew of airline B"; "Airlines A and B share the same landing slot at an airport"; and "I had not noticed this and/or do not know what it means". The answer options are randomized across respondents to prevent order effects. Importantly, after seeing this question, respondents were not able to go back to the stated preference experiment to alter their choices.

Risk attitudes are captured using two types of questions. The first type asks respondents to give

\footnotetext{
${ }^{9}$ In these pilot studies, the stated preference scenarios were adapted to reflect flight choices in long-haul non-stop markets from Amsterdam, The Netherlands (Amsterdam Airport Schiphol, AMS) to Nairobi, Kenia (Jomo Kenyatta International Airport, NBO) and to New York (John F. Kennedy International Airport, JFK). It is noteworthy that in these different route markets the main findings were qualitatively similar to the findings in the trans-Pacific route markets presented in this paper.
} 
a global assessment of their willingness to take risks. The second type deals with the willingness to take risks in three specific domains that are relevant in our research context: finances, health/safety and recreation. ${ }^{10}$ This way of measuring risk attitudes is in line with recent studies that show that the usual practice of measuring risk attitudes using lottery-style experiments generalizes poorly to risk behavior outside the financial realm, and that self-assessed measures of risk attitude that pertain to the specific research context often have better predictive validity (e.g., Dohmen et al., 2011). The exact wording and the scale of the risk attitude question was taken from the seminal study by Dohmen et al. (2011).

\subsection{Sample and descriptives}

In June 2018, we distributed the stated preference experiment to a sample of Australian air travel consumers. The respondents are from the Pureprofile Australian panel as built for the Values project. ${ }^{11}$ This panel, based on a cross-sequential design includes 7000 respondents between 18 and 75 years. Respondents in the panel fill out surveys for which they earn a fee that can later be redeemed for a reward. For our study, we aimed at 500 complete responses of respondents who qualified our criterium of taking a flight in the last 12 months and living in the Eastern States; this criterium had an incidence rate of $53 \%$. Our final sample consists of 502 respondents, who took on average 11.3 minutes to finalize our survey.

Table 3 provides descriptives of the respondents in our sample and of the Australian population in general. Most of the sociodemographics of our sample match closely with those in the general Australian population, underscoring the representativeness of our sample. ${ }^{12}$ With respect to the statistics on air travel behavior, we document that, conditional on flying at least once, Australians fly on average 2.5 roundtrip per year. The majority of respondents flies internationally $(65.5 \%)$, whereas a minority flies for business purposes (17.5\%). Finally, consistent with de Jong et al. (2019), there is a noteworthy discrepancy between membership of the frequent flier program of the own national carrier, Qantas (62.0\%), and the neighboring national carrier, Air New Zealand (1.0\%).

\footnotetext{
${ }^{10}$ We choose these specific domains because in considering the risks of traveling with an alien carrier, consumers may take into account financial consequences (e.g., invalidated tickets or lost luggage), health/safety consequences (e.g., potential for accidents). Recreation and travelling are often closely connected, recreational risks are therefore also relevant.

${ }^{11}$ For details see https://business.pureprofile.com/values-report/

${ }^{12}$ This is not the case for age and university degree, although this can be attributed to the fact that individuals below 18 years are not included in the consumer panel which biases the sample means of age and university degree upwards.
} 
Table 3: Sample descriptives

\begin{tabular}{|c|c|c|c|c|c|}
\hline \multirow[b]{2}{*}{ Variable } & \multirow{2}{*}{$\frac{\text { Population }}{\text { Mean }}$} & \multicolumn{4}{|c|}{ Sample } \\
\hline & & Mean & Std. dev. & Min & Max \\
\hline \multicolumn{6}{|l|}{ Socio-demographics: } \\
\hline Female & 0.507 & 0.532 & 0.499 & 0 & 1 \\
\hline Age & 38.650 & 48.398 & 15.722 & 19 & 77 \\
\hline Australian nationality & 0.824 & 0.892 & 0.310 & 0 & 1 \\
\hline English mother tongue & 0.901 & 0.886 & 0.318 & 0 & 1 \\
\hline Employed & 0.603 & 0.625 & 0.484 & 0 & 1 \\
\hline Student & 0.076 & 0.040 & 0.196 & 0 & 1 \\
\hline University degree & $0.220^{a}$ & 0.373 & 0.484 & 0 & 1 \\
\hline \multicolumn{6}{|l|}{ Air travel behavior: } \\
\hline \# of flights in past 12 months & $\mathrm{N} / \mathrm{A}$ & 2.590 & 3.746 & 1 & 50 \\
\hline international traveler & $\mathrm{N} / \mathrm{A}$ & 0.655 & 0.476 & 0 & 1 \\
\hline business traveler & $\mathrm{N} / \mathrm{A}$ & 0.175 & 0.381 & 0 & 1 \\
\hline Qantas frequent flier & $\mathrm{N} / \mathrm{A}$ & 0.620 & 0.486 & 0 & 1 \\
\hline Air New Zealand frequent flier & $\mathrm{N} / \mathrm{A}$ & 0.010 & 0.099 & 0 & 1 \\
\hline
\end{tabular}

Note(s): Australian population statistics obtained from Australian Bureau of Statistics (2018). ${ }^{a}$ the percentage of university degree in the Australian population of 15 years or older.

Figure 1 shows the distribution of respondents' answers to the codeshare definition answer. In line with prior literature (Goh and Uncles, 2003), we document great variation in the conceptions of codesharing across the population. The group with the correct conception of codesharing accounts for less than half of the sample (232 respondents). A substantial group (154 respondents) is aware that codesharing entails some sort of a partnership between the involved carriers, however does not know that this implies that they will be flying on an airplane and with a crew of a different carrier than the one that is selling the tickets. Another rather large group (85 respondents) concedes that they either do not know what codesharing means or had not noticed that some flights were codeshared during the experiment. Finally, a small group (31 respondents) wrongly believes that codesharing implies that two carriers share a landing slot at an airport.

Figure 2 shows the distribution of answers to the risk indicators. Following Dohmen et al. (2011), respondents rated their risk attitude on a scale from 10 to 0 , where 10 meant "not at all willing to take risks" and 0 "very willing to take risks". Overall, the distributions show that there is substantial variation in risk attitude across the respondents. General and recreational risk attitude are more normally distributed, whereas financial and health/safety risk attitude are slightly more right-skewed - implying more risk-aversion in these domains. It is also noteworthy that the risk indicators are not perfectly correlated, although pair-wise correlations are generally high at 0.57 0.77 (see Appendix B for the correlation matrix). This is in line with the literature and warrants the use of domain-specific risk indicators. 
Figure 1: Distribution of codeshare (mis)conceptions

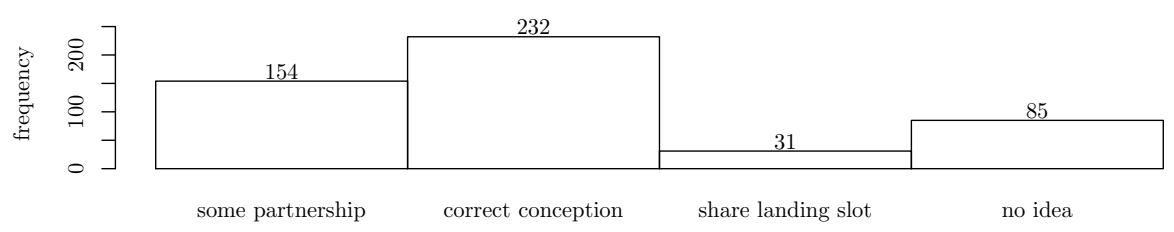

Figure 2: Distribution of risk indicators
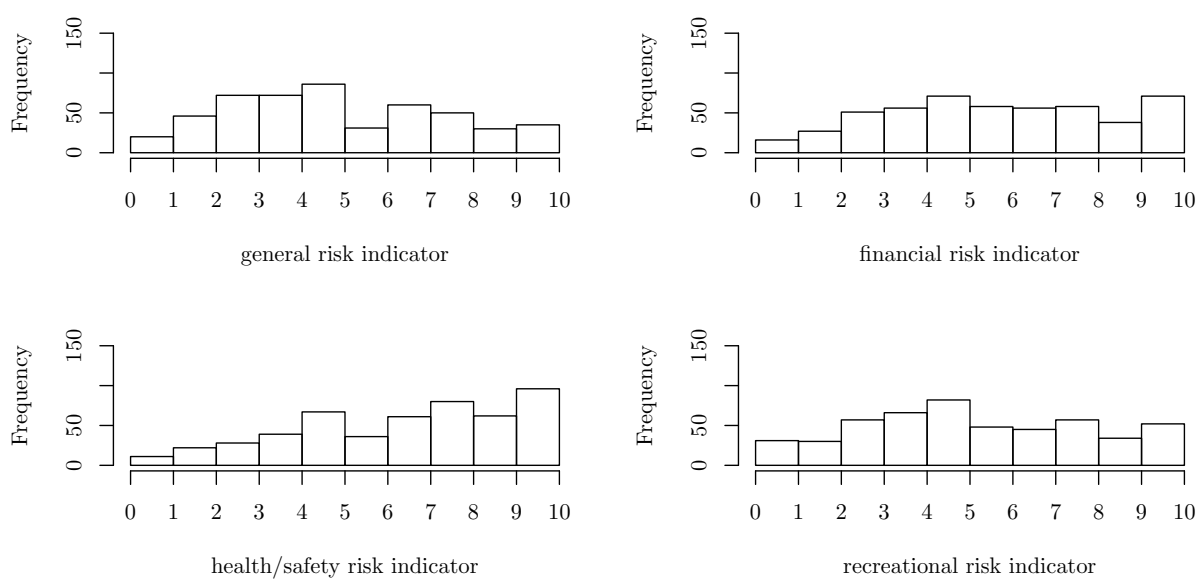

\section{Econometric approach}

We use a discrete choice framework to elicit consumer valuations for the flight products that appear during the stated preference experiment. We start with multinomial logit models that estimate average differences in willingness-to-pay between the flight products. Subsequently, we specify panel mixed logit models that correct for the panel structure of the data and allow for unobserved preferences for flight products across consumers. To examine codeshare (mis)conceptions and riskaversion as two behavioral mechanisms underlying choice behavior, we specify a hybrid panel mixed logit model in the spirit of, among others, Ben-Akiva et al. (2002) and Ashok et al. (2002). This model links individuals' codeshare (mis)conceptions and risk-aversion to their valuation of each flight product, while explicitly taking into account that risk attitude is unobserved and therefore contains substantial measurement error. ${ }^{13}$ To reveal differences in choice behavior between less and more

\footnotetext{
${ }^{13} \mathrm{We}$ acknowledge that codeshare (mis)conceptions may also be measured with some error. However, as (mis)conceptions are measured using a multiple-choice type of question (instead of an arbitrary scale) measurement
} 
familiar markets, all models are estimated separately for the Santiago and San Francisco destination markets.

\subsection{Multinomial and panel mixed logit}

In line with random utility theory (McFadden, 1974), we assume that the utility that individual, $n$, derives from flight alternative, $i$, in choice scenario, $t$, can be decomposed into a deterministic component that depends on observed characteristics of the alternatives (i.e., the type of flight product, travel time and ticket fare) and a stochastic component that captures unobserved idiosyncrasies:

$$
U_{n i t}=V_{n i t}\left(d_{\text {lnit }}, t_{n i t}, p_{n i t}\right)+\varepsilon_{n i t},
$$

where $d_{\text {lnit }}$ is a vector of $L$ dummies for flight products; and $t_{n i t}$ and $p_{n i t}$ are the travel time and ticket fare, respectively.

Following Train and Weeks (2005) we use a specification in willingness-to-pay space for the deterministic component of utility:

$$
V_{n i t}=\gamma\left(\alpha_{l n} d_{l n i t}+\beta t_{n i t}-p_{n i t}\right),
$$

where the parameters of main interest, $\alpha_{l n}$, provide the willingness-to-pay for flight products; $\beta$ provides the willingness-to-pay for a one unit change in travel time; and $\gamma$ is the cost parameter which incorporates scale and hence has no direct interpretation (Train and Weeks, 2005). ${ }^{14}$

Assuming utility-maximizing behavior and an independent, identically extreme value distribution for the error term, $\varepsilon_{n i t}$, leads to the well-known logit choice probability of individual $n$ choosing flight alternative $i$ :

$$
P_{n}(i)=\frac{e^{\gamma\left(\alpha_{l n} d_{l n i t}+\beta t_{n i t}-p_{n i t}\right)}}{\sum_{j=1}^{J} e^{\gamma\left(\alpha_{l n} d_{l n j t}+\beta t_{n j t}-p_{n j t}\right)}}, i \in J,
$$

which can be estimated using standard likelihood procedures.

To correct for the panel structure of the data and allow for unobserved preferences for flight products, we include a random term to the flight product parameters: $\alpha_{l n}=\alpha_{l 0}+\alpha_{l \sigma} \psi_{l n}$, where

error is presumably of much less concern.

${ }^{14}$ In most of our specifications, the willingness-to-pay space transformation is formally equivalent to the more usual preference space specification (i.e., it provides identical results). In a robustness check that allows for random cost parameters, the willingness-to-pay space transformation enables us to directly specify the distribution of willingnessto-pay. This typically leads to more reasonable distributions, compared with distributions that are derived post-hoc from the coefficients of a specification in preference space (Train and Weeks, 2005). 
$\psi_{l n}$ is an individual-specific standard normally distributed random term; and $\alpha_{l \sigma}$ is the random scale parameter to be estimated.

This addition leads to the panel mixed logit probability of individual $n$ making the sequence of flight choices $\mathbf{i}=\left\{i_{1}, \ldots, i_{T}\right\}$ :

$$
P_{n}(\mathbf{i})=\int \prod_{t=1}^{T}\left[\frac{e^{\gamma\left(\alpha_{l n} d_{l n i t}+\beta t_{n i t}-p_{n i t}\right)}}{\sum_{j=1}^{J} e^{\gamma\left(\alpha_{l n} d_{l n j t}+\beta t_{n j t}-p_{n j t}\right)}}\right] f(\psi) d \psi, i \in J,
$$

which can be estimated by simulated maximum likelihood procedures (see, e.g., Train, 2009). ${ }^{15}$

\subsection{Hybrid panel mixed logit}

To examine codeshare misconceptions and risk-aversion as two behavioral mechanisms underlying choices between pure online and virtual codeshare flight products, we rewrite the flight product parameters as follows: $\alpha_{l n}=\alpha_{l 0}+\alpha_{l 1} m s c_{n}+\alpha_{l 2} r s k_{n}^{*}+\alpha_{l \sigma} \psi_{l n}$, where $m s c_{n}$ is a dummy equal to one for individuals with a misconception of codesharing and zero otherwise; $r s k_{n}^{*}$ represents each individuals (latent) risk attitude; $\alpha_{l 0}$ gives the baseline flight product valuation; and $\alpha_{l 1}$ and $\alpha_{l 2}$ give the variations in flight product valuations related to codeshare misconceptions and risk attitude. ${ }^{16}$

As risk attitude is latent it is not directly observed, but characterized by a structural equation:

$$
r s k_{n}^{*}=\theta_{v} s_{n v}+\theta_{\sigma} \omega_{n}
$$

where $s_{n v}$ is a vector of $V$ sociodemographics; $\theta_{v}$ is a vector of associated parameters to be estimated; $\omega_{n}$ is an individual-specific standard normally distributed random term; and $\theta_{\sigma}$ is the scale parameter. ${ }^{17}$

Information about (latent) risk attitude is obtained from the risk indicators. The relationship between (latent) risk attitude and the $R$ risk indicators is given by the following measurement

\footnotetext{
${ }^{15}$ Our initial specification assumes independence between individuals' unobserved preferences for specific flight products. This assumption is relaxed in a robustness checks where we allow for correlations between an individual's unobserved preference for pure online products and codeshared products offered by the same carrier.

${ }^{16}$ Due to the coding of $m s c_{n}$ and $r s k_{n}$, the baseline flight product parameters represent the valuation of individuals that have a misconception of codesharing and an average risk attitude (i.e., neither risk-averse nor risk-seeking); the parameter associated with $m s c_{n}$ represents the difference in carrier preferences between individuals that have the wrong and correct conception of codesharing; and the parameter associated with $r s k_{n}^{*}$ yields the changes in carrier preferences for a one standard deviation increase in (latent) risk attitude.

${ }^{17}$ In search of a parsimonious specification, we started with including all sociodemographics listed in Table 3 and maintained only those that were significantly related to (latent) risk attitude (i.e., gender, age, university degree, employment status).
} 
equation:

$$
I_{r n}=\delta_{r 0}+\delta_{r 1} r s k_{n}^{*}+\delta_{r \sigma} \eta_{r n}
$$

where $\delta_{r 0}$ and $\delta_{r 1}$ are parameters to be estimated; and $\eta_{r n}$ is an error term.

Assuming a normal distribution for the error term of the measurement equation, $\eta_{r n}$, the conditional probability of observing the sequence of risk indicators $\mathbf{I}=\left\{I_{1}, \ldots, I_{R}\right\}$ is:

$$
P_{n}(\mathbf{I} \mid \omega)=\prod_{r=1}^{R}\left[\frac{1}{\sqrt{2 \pi \sigma^{2}}} e^{-\frac{\left(I_{r n}-\left(\delta_{r 0}+\delta_{r 1} r s k_{n}^{*}\right)\right)^{2}}{2 \sigma^{2}}}\right]
$$

The probability of each individual (i.e., joint probability of the sequences of choices and risk indicators per individual) can than be expressed as:

$$
\begin{aligned}
P_{n}(\mathbf{i}, \mathbf{I})=\int & \int \prod_{t=1}^{T}\left[\frac{e^{\gamma\left(\alpha_{l n} d_{l n i t}+\beta t_{n i t}-p_{n i t}\right)}}{\sum_{j=1}^{J} e^{\gamma\left(\alpha_{l n} d_{l n j t}+\beta t_{n j t}-p_{n j t}\right)}}\right] \\
& \times \prod_{r=1}^{R}\left[\frac{1}{\sqrt{2 \pi \sigma^{2}}} e^{-\frac{\left(I_{r n}-\left(\delta_{r 0}+\delta_{r 1} r s k_{n}^{*}\right)\right)^{2}}{2 \sigma^{2}}}\right] f(\omega) f(\psi) d \omega d \psi,
\end{aligned}
$$

which can be estimated using simulated maximum likelihood estimation. ${ }^{18}$

To estimate hybrid choice models, the latent variable needs to be normalized. Two common approaches are normalizing the parameters of one of the measurement equations, or normalizing the variance of the structural equation error term (Vij and Walker, 2016). We opt for the latter approach, as it has been shown to lead to parameter estimates that are closer to the underlying data generation process (Raveau et al., 2012). An additional advantage of this normalization is that the latent variable parameter in the choice model can be interpreted as the change in flight product valuations for a one standard deviation in (latent) risk attitude. ${ }^{19}$

In simulated maximum likelihood estimation, the choice of good starting values is critical. We follow the practice of Hess and Train (2017) by first estimating restricted versions of the model and then using the obtained estimates as starting values for more extended versions. In particular, the estimates of the multinomial logit are used as starting values for the panel mixed logit. Starting values for the hybrid panel mixed logit are obtained by first estimating the choice and the measurement/structural component separately (Bierlaire, 2016a).

\footnotetext{
${ }^{18}$ As our model specification only includes one latent variable we use this conventional estimation approach. For models with multiple latent variables, the approach by Bhat and Dubey (2014) offers an attractive alternative.

${ }^{19}$ We note here that we estimated our preferred model specification with the other normalization approach which led to very similar results. These model estimation results are available upon request.
} 


\section{Model estimation results}

\subsection{Multinomial and panel mixed logit results}

Table 4 provides the multinomial and mixed logit results. Columns (1) and (2) provide the parameter estimates for the multinomial (Eq. 3) and mixed logit specifications (Eq. 4) in the Santiago destination market, whereas columns (3) and (4) provide the estimates for these models in the San Francisco destination market. In all estimation results reported in the main text, we consider the five broad types of flight products described in section 2: pure online flights by Qantas (QF/QF), pure online flights by Air New Zealand (NZ/NZ), codeshared flights by Qantas (*/QF), codeshared flights by Air New Zealand $(* / \mathrm{NZ})$ and pure online flights by alien carriers $(* / *) .{ }^{20}$ Pure online flights by alien carriers represents the reference category. Consequently, the reported parameter estimates associated with the flight products should be interpreted as the additional willingness-to-pay in Australian dollars (AUD) relative to the alien pure online product.

In terms of model fit, the panel mixed logit model offers a significant improvement over the multinomial logit model in the Santiago destination market $\left(\chi^{2}=278.97, d f=4, p<.01\right)$, as well as in the San Francisco destination market $\left(\chi^{2}=282.72, d f=4, p<.01\right)$. This underlines the importance of correcting for the panel structure of the data and justifies our focus on the parameter estimates obtained from the panel mixed logit model. ${ }^{21}$

In both destination markets, the baseline flight product parameters are large in magnitude and highly statistically significant. This implies that, on average, consumers have substantial willingnessto-pay for pure online as well as virtual codeshare flight products offered by Qantas and Air New Zealand, relative to pure online flight products offered by alien carriers. Consumers are willing to pay the highest premium for the pure online products by their own national carrier, Qantas, at 134 AUD (87 AUD) or approximately $7.5 \%(5 \%)$ of the average ticket fare in the Santiago (San Francisco) destination market. More importantly for the objective of the current study, consumers are also willing to pay a substantial premium for virtual codeshare products operated by alien carriers but

\footnotetext{
${ }^{20}$ In initial model specifications, we considered each distinct combination of operating and marketing carrier as a separate product category (see Appendix C for the estimation results). The parameter estimates of these specifications indicated that there are no substantial and robustly significant differences in consumers' valuation of the flight products by the different alien carriers. This suggests that consumers regard these carriers more or less as perfect substitutes and allows us to aggregate the alien carriers in a single flight product category.

${ }^{21}$ It should be added that the parameter estimates from the multinomial logit are not widely different from those in the panel mixed logit.
} 
Table 4: Multinomial and panel mixed logit estimation results

\begin{tabular}{|c|c|c|c|c|c|c|c|c|}
\hline \multirow{3}{*}{$\begin{array}{l}\text { Parameters } \\
\text { QF/QF baseline } \\
\text { QF/QF random scale }\end{array}$} & \multicolumn{4}{|c|}{ Santiago destination market } & \multicolumn{4}{|c|}{ San Francisco destination market } \\
\hline & \multicolumn{2}{|c|}{$(1)$} & \multicolumn{2}{|c|}{$(2)$} & \multicolumn{2}{|c|}{$(3)$} & \multicolumn{2}{|c|}{$(4)$} \\
\hline & $147.70^{* *}$ & $(5.53)$ & $\begin{array}{l}134.33^{* *} \\
80.32^{* *}\end{array}$ & $\begin{array}{l}(6.18) \\
(6.75)\end{array}$ & $98.08^{* *}$ & $(4.64)$ & $\begin{array}{l}86.84^{* *} \\
82.26^{* *}\end{array}$ & $\begin{array}{l}(5.71) \\
(6.96)\end{array}$ \\
\hline $\begin{array}{l}\mathrm{NZ} / \mathrm{NZ} \text { baseline } \\
\mathrm{NZ} / \mathrm{NZ} \text { random scale }\end{array}$ & $97.90^{* *}$ & $(5.31)$ & $\begin{array}{l}83.31^{* *} \\
52.23^{* *}\end{array}$ & $\begin{array}{l}(5.42) \\
(7.00)\end{array}$ & $62.44^{* *}$ & $(4.70)$ & $\begin{array}{l}50.88^{* *} \\
57.49^{* *}\end{array}$ & $\begin{array}{l}(5.33) \\
(7.04)\end{array}$ \\
\hline $\begin{array}{l}* / \text { QF baseline } \\
* / \text { QF random scale }\end{array}$ & $108.96^{* *}$ & $(4.65)$ & $\begin{array}{l}96.09^{* *} \\
70.33^{* *}\end{array}$ & $\begin{array}{l}(5.15) \\
(5.22)\end{array}$ & $76.83^{* *}$ & $(3.95)$ & $\begin{array}{l}68.28^{* *} \\
65.08^{* *}\end{array}$ & $\begin{array}{l}(4.61) \\
(4.70)\end{array}$ \\
\hline $\begin{array}{l}* / \mathrm{NZ} \text { baseline } \\
* / \mathrm{NZ} \text { random scale }\end{array}$ & $73.06^{* *}$ & $(4.53)$ & $\begin{array}{l}62.91^{* *} \\
44.58^{* *}\end{array}$ & $\begin{array}{l}(4.50) \\
(5.53)\end{array}$ & $40.42^{* *}$ & (3.99) & $\begin{array}{l}33.22^{* *} \\
44.05^{* *}\end{array}$ & $\begin{array}{l}(4.17) \\
(5.18)\end{array}$ \\
\hline $\begin{array}{l}\text { Travel time } \\
\text { Cost parameter }\end{array}$ & $\begin{array}{l}-0.92^{* *} \\
0.02^{* *}\end{array}$ & $\begin{array}{l}(0.05) \\
(0.00)\end{array}$ & $\begin{array}{l}-0.91^{* *} \\
0.02^{* *}\end{array}$ & $\begin{array}{l}(0.04) \\
(0.00)\end{array}$ & $\begin{array}{l}-0.88^{* *} \\
0.02^{* *}\end{array}$ & $\begin{array}{l}(0.04) \\
(0.00)\end{array}$ & $\begin{array}{l}-0.90^{* *} \\
0.02^{* *}\end{array}$ & $\begin{array}{l}(0.04) \\
(0.00)\end{array}$ \\
\hline $\begin{array}{l}\text { Observations (choice) } \\
\text { Individuals } \\
\text { Parameters } \\
\text { Draws (MLHS) } \\
\text { Log likelihood } \\
\end{array}$ & -283 & & $\begin{array}{r}3 \\
5 \\
5 \\
-269 \\
\end{array}$ & & -29 & & $\begin{array}{r}3 \\
-27 \\
\end{array}$ & \\
\hline
\end{tabular}

Note(s): All models are estimated using BIOGEME (Bierlaire, 2016b). Draws in panel mixed logit are according to Modified Latin Hybercube Sampling (MLHS, see, Hess et al., 2006). Standard errors in parentheses. ${ }^{*} \mathrm{p}<0.05 ;{ }^{* *} \mathrm{p}<0.01$

offered through Qantas. This premium equals 96 AUD (68 AUD) or approximately 5.5\% (4\%) in the Santiago (San Francisco) destination market. Pure online and codeshared products by Air New Zealand command somewhat lower, although still considerable, premiums of respectively 83 and 63 AUD (51 and 33 AUD) or approximately 5 and 3.5\% (3 and 2\%) in the Santiago (San Francisco) destination market.

The random scale parameters are also highly statistically significant, indicating that there is substantial heterogeneity in willingness-to-pay for each flight product across consumers. Using the baseline and random scale parameters, we estimate the distribution of willingness-to-pay for each flight product. From these distributions, we derive that the share of the population with a positive willingness-to-pay in the Santiago (San Francisco) destination market, is equal to $95.5 \%$ (85.5\%) for pure online products by Qantas, 94.5\% (81\%) for pure online products by Air New Zealand, 91.5\% (85.5\%) for virtual codeshare products by Qantas and $92 \%$ (77.5\%) for virtual codeshare products by Air New Zealand. Thus, although the magnitude of the premiums varies a lot across consumers, the vast majority of the population has a positive willingness-to-pay for pure online and virtual codeshare flight products by Qantas and Air New Zealand, relative to pure online products by alien carriers. 


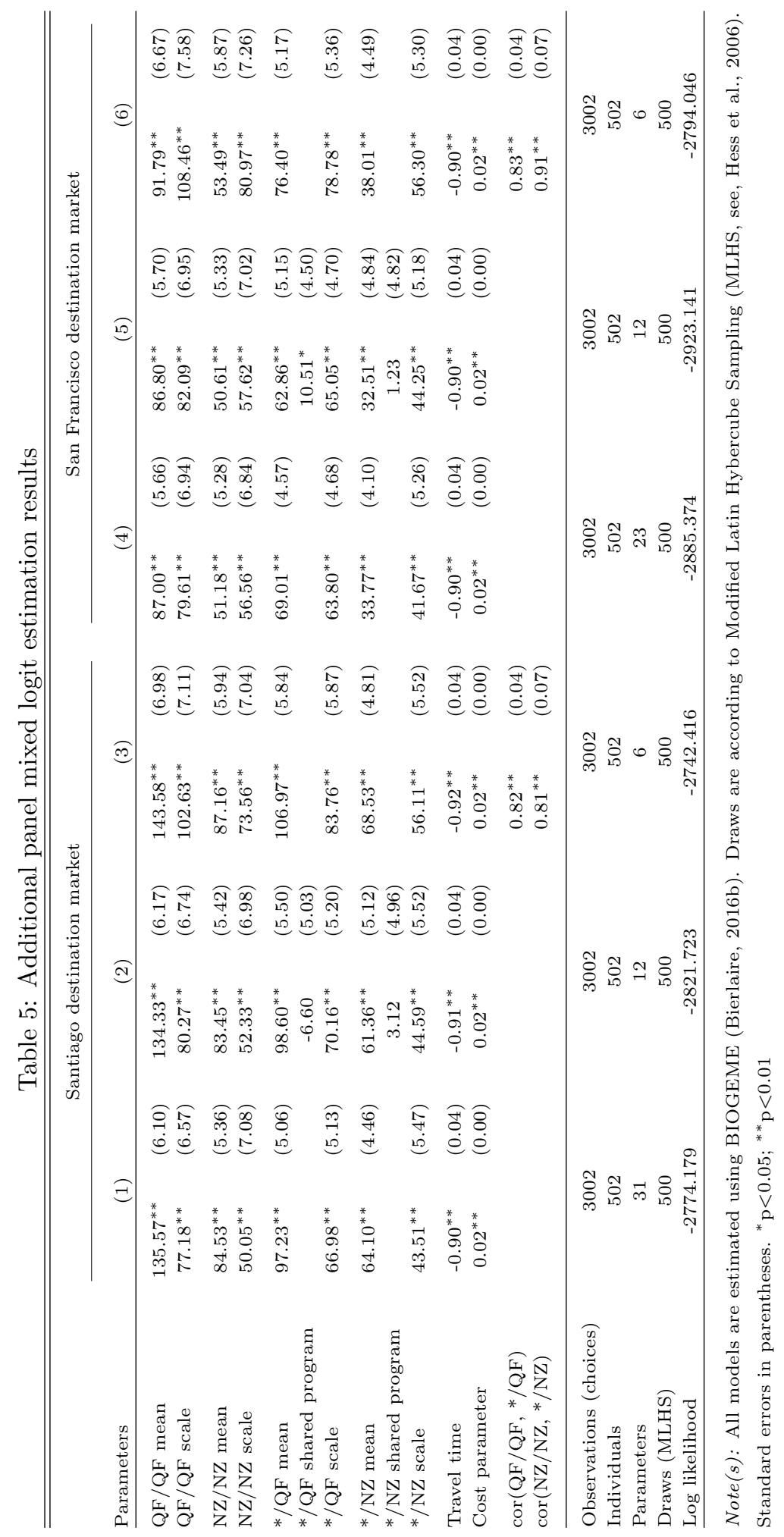


To test the robustness of these findings, Table 5 provides the results of three additional panel mixed logit estimations in the Santiago and San Francisco destination market, respectively. Columns (1) and (4) report the parameter estimates of a specification that includes a large range of covariates, including Qantas frequent flier program membership. ${ }^{22}$ The other covariates that are included are: gender, age, Australian nationality, trip frequency and whether the respondents frequently travels internationally and/or for business purposes. ${ }^{23}$ Inclusion of these covariates leads to parameter estimates that are virtually identical to those in the specifications of columns (2) and (4) in Table 4. Most importantly, this rules out frequent flier program membership as an explanation for the differences in consumer valuation of the flight products in our analysis.

To provide an additional check on the potential influence of frequent flier programs, we consider in columns (2) and (5) the difference in valuation of codeshare products involving operating and marketing carriers that in reality share their frequent flier program. If willingness-to-pay for codeshared products is due to frequent flier programs, the valuation of codeshared products should be larger for codeshared products among carriers that in reality have integrated programs. We find that the virtual codeshare product that is marketed by Qantas and operated by American Airlines $(\mathrm{AA} / \mathrm{QF})$ is valued higher than the codeshare product that is marketed by Qantas and operated by United Airlines (UA/QF). However, the effect is rather small. Moreover, in the destination market where the willingness-to-pay for codeshare products is highest (Santiago), we do not find that virtual codesharing among carriers with integrated programs is higher. This finding is in line with the aforementioned finding: frequent flier programs do not seem to play a prominent role in the estimated willingness-to-pay. ${ }^{24}$

Finally, in columns (3) and (6), we extend our specification by allowing for correlations in individuals unobserved preferences for pure online and codeshare products offered by the same carrier. Specifically, the parameter $\rho_{1}$ captures correlation between pure online and codeshare products by Qantas, while $\rho_{2}$ captures correlation between pure online and codeshare products by Air New

\footnotetext{
${ }^{22}$ Inclusion of Air New Zealand frequent flier program membership was not feasible due to the small share of respondents that are member of this program.

${ }^{23}$ To constrain the computational burden associated with the large number of additional parameters to be estimated, we start with an initial run of a multinomial logit model including all covariates and drop all interaction terms that are not statistically significant at the $10 \%$ confidence level from the subsequent panel mixed logit model estimation. Parameter estimates on the covariates are available upon request.

${ }^{24}$ Recall that we tried to preclude the effect of frequent flier programs in the experiment by explicitly telling respondents that they could not earn or spend frequent flier programs on any of the flight products. Our findings regarding the impact of frequent flier program membership suggests that this has been effective.
} 
Table 6: Hybrid panel mixed logit estimation results

\begin{tabular}{|c|c|c|c|c|c|c|c|c|}
\hline \multirow{3}{*}{$\frac{\text { Parameters }}{\mathrm{QF} / \mathrm{QF} \text { baseline }}$} & \multicolumn{4}{|c|}{ Santiago destination market } & \multicolumn{4}{|c|}{ San Francisco destination market } \\
\hline & \multicolumn{2}{|c|}{ (1) } & \multicolumn{2}{|c|}{$(2)$} & \multicolumn{2}{|c|}{ (3) } & \multicolumn{2}{|c|}{ (4) } \\
\hline & $154.75^{* *}$ & $(9.17)$ & $164.38^{* *}$ & $(10.60)$ & $103.73^{* *}$ & $(8.57)$ & $99.71^{* *}$ & $(9.71)$ \\
\hline $\mathrm{QF} / \mathrm{QF}$ misconception & $-31.00^{* *}$ & $(11.20)$ & $-27.97^{*}$ & $(11.30)$ & $-21.89^{*}$ & (10.90) & $-23.75^{*}$ & $(11.00)$ \\
\hline $\mathrm{QF} / \mathrm{QF}$ risk attitude & $25.86^{* *}$ & $(5.76)$ & $21.39^{* *}$ & $(6.38)$ & $15.86^{* *}$ & $(5.56)$ & $17.63^{* *}$ & $(6.17)$ \\
\hline $\mathrm{QF} / \mathrm{QF}$ risk attitude ${ }^{2}$ & & & -10.21 & $(5.67)$ & & & 4.13 & $(5.02)$ \\
\hline $\mathrm{QF} / \mathrm{QF}$ random scale & $76.61^{* *}$ & $(6.85)$ & $75.66^{* *}$ & $(6.88)$ & $78.80^{* *}$ & $(7.10)$ & $78.64^{* *}$ & $(7.07)$ \\
\hline NZ/NZ baseline & $109.56^{* *}$ & $(7.65)$ & $122.94^{* *}$ & $(9.08)$ & $72.74^{* *}$ & $(7.01)$ & $76.47^{* *}$ & $(8.06)$ \\
\hline $\mathrm{NZ} / \mathrm{NZ}$ misconception & $-41.03^{* *}$ & $(9.72)$ & $-37.73^{* *}$ & $(9.81)$ & $-31.01^{* *}$ & $(9.45)$ & $-29.50^{* *}$ & $(9.52)$ \\
\hline NZ/NZ risk attitude & $17.81^{* *}$ & $(5.00)$ & $13.47^{*}$ & $(5.87)$ & $10.01^{*}$ & $(5.01)$ & 8.19 & $(5.62)$ \\
\hline $\mathrm{NZ} / \mathrm{NZ}$ risk attitude ${ }^{2}$ & & & $-14.02^{* *}$ & $(5.14)$ & & & -4.94 & $(4.77)$ \\
\hline $\mathrm{NZ/NZ}$ random scale & $40.76^{* *}$ & $(7.80)$ & $39.91^{* *}$ & $(8.05)$ & $46.87^{* *}$ & $(7.30)$ & $47.38^{* *}$ & $(7.29)$ \\
\hline */QF baseline & $96.01^{* *}$ & $(7.63)$ & $96.80^{* *}$ & $(8.98)$ & $62.39^{* *}$ & $(6.86)$ & $54.69^{* *}$ & $(7.85)$ \\
\hline */QF misconception & 7.63 & $(9.61)$ & 8.37 & $(9.68)$ & 14.67 & $(8.92)$ & 11.50 & $(8.88)$ \\
\hline */QF risk attitude & $18.58^{* *}$ & $(4.94)$ & $16.57^{* *}$ & $(5.13)$ & 7.05 & $(4.73)$ & $11.68^{*}$ & $(5.43)$ \\
\hline$* / \mathrm{QF}$ risk attitude ${ }^{2}$ & & & -1.63 & $(5.01)$ & & & $9.39^{*}$ & $(4.32)$ \\
\hline */QF random scale & $67.06^{* *}$ & $(5.15)$ & $66.78^{* *}$ & $(5.15)$ & $64.14^{* *}$ & $(4.76)$ & $62.90^{* *}$ & $(4.77)$ \\
\hline */NZ baseline & $68.75^{* *}$ & $(6.64)$ & $77.11^{* *}$ & $(7.77)$ & $40.81^{* *}$ & $(5.99)$ & $44.77^{* *}$ & $(6.88)$ \\
\hline */NZ misconception & -7.59 & $(8.49)$ & -5.84 & $(8.62)$ & -10.84 & $(7.82)$ & -9.83 & $(7.87)$ \\
\hline */NZ risk attitude & 7.19 & $(4.43)$ & 3.83 & $(4.98)$ & 4.64 & $(4.09)$ & 2.27 & $(4.65)$ \\
\hline$* / \mathrm{NZ}_{\text {risk attitude }}{ }^{2}$ & & & $-9.05^{*}$ & $(4.29)$ & & & -4.76 & $(3.81)$ \\
\hline$* / \mathrm{NZ}$ random scale & $42.55^{* *}$ & $(5.54)$ & $43.25^{* *}$ & $(5.49)$ & $38.49^{* *}$ & $(5.56)$ & $38.91^{* *}$ & $(5.55)$ \\
\hline Travel time & $0.02^{* *}$ & $(0.00)$ & $0.02^{* *}$ & $(0.00)$ & $0.02^{* *}$ & $(0.00)$ & $0.02^{* *}$ & $(0.00)$ \\
\hline Cost parameter & $-0.91^{* *}$ & $(0.04)$ & $-0.92^{* *}$ & $(0.04)$ & $-0.90^{* *}$ & $(0.04)$ & $-0.90^{* *}$ & $(0.04)$ \\
\hline Observations (choice) & \multicolumn{2}{|c|}{3002} & \multicolumn{2}{|c|}{3002} & \multicolumn{2}{|c|}{3002} & \multicolumn{2}{|c|}{3002} \\
\hline Individuals & \multicolumn{2}{|c|}{502} & \multicolumn{2}{|c|}{502} & \multicolumn{2}{|c|}{502} & \multicolumn{2}{|c|}{502} \\
\hline Parameters & \multicolumn{2}{|c|}{35} & \multicolumn{2}{|c|}{39} & \multicolumn{2}{|c|}{35} & \multicolumn{2}{|c|}{39} \\
\hline Draws (MLHS) & \multicolumn{2}{|c|}{500} & \multicolumn{2}{|c|}{500} & \multicolumn{2}{|c|}{500} & \multicolumn{2}{|c|}{500} \\
\hline Log likelihood & \multirow{2}{*}{\multicolumn{2}{|c|}{-6824.158}} & \multicolumn{2}{|c|}{-6818.552} & \multicolumn{2}{|c|}{-6949.672} & \multicolumn{2}{|c|}{-6943.664} \\
\hline Log likelihood (choice) & & -2660.78 & \multicolumn{2}{|c|}{-2653.83} & \multicolumn{2}{|c|}{-2780.42} & -27 & \\
\hline
\end{tabular}

Note(s): All models are estimated using BIOGEME (Bierlaire, 2016b). Draws are according to Modified Latin Hybercube Sampling (MLHS, see, Hess et al., 2006). Standard errors in parentheses. ${ }^{*} \mathrm{p}<0.05 ;{ }^{* *} \mathrm{p}<0.01$

Zealand. These correlations are highly statistically significant and very strong $(>0.8)$ in both destination markets, indicating that, not surprisingly, consumers who have a strong unobserved preference for pure online products by Qantas (Air New Zealand) generally also have a strong unobserved preference for its virtual codeshare products.

\subsection{Hybrid panel mixed logit results}

Table 6 provides the estimation results of the hybrid panel mixed logit models that links individuals' (mis)conceptions about codesharing and risk attitude to their valuations of the flight products. Columns (1) and (3) provide the parameter estimates of the standard hybrid panel mixed logit 
specification (Eq. 8), for respectively the Santiago and San Francisco destination markets. Columns (2) and (4) provide the parameter estimates of extensions in which risk attitude is allowed to have an increasing or decreasing impact over its range. ${ }^{25}$

To assess model fit of the hybrid panel mixed logit models, we factor out the portion of the log likelihood that relates to the choice component of the hybrid panel mixed logit models. ${ }^{26}$ This shows that the hybrid panel mixed logit yields a significant improvement in model fit as compared with the panel mixed logit $\left(\chi^{2}=62.86, d f=12, p<.01\right.$ in the Santiago destination market; and $\chi^{2}=27.25$, $d f=12, p<.01$ in the San Francisco destination market). The inclusion of a non-linear impact of risk attitude leads to a further improvement in model fit in the Santiago destination market $\left(\chi^{2}=\right.$ 13.90, $d f=4, p<.01)$, but not in the San Francisco destination market $\left(\chi^{2}=4.88, d f=4, p>\right.$ $.05)$.

The estimates of the misconception parameters in Table 6 represent the difference in the premium that consumers with the correct versus wrong conception of codesharing are willing to pay for each product type. Interestingly, consumers with a misconception of codesharing are willing to pay a lower premium for pure online products by Qantas and Air New Zealand, relative to consumers with the correct conception of codesharing. This premium is approximately 31 and 41 AUD (22 and 31 AUD) lower for, respectively, Qantas and Air New Zealand in the Santiago (San Francisco) destination market. Furthermore, there is no significant impact of codeshare misconceptions on the premium for codesharing by Qantas and Air New Zealand. In other words, codeshare misconceptions do not lead to a higher willingness-to-pay for codeshared over pure online alien flights.

These effects are illustrated in Figure 3, which show the willingness-to-pay for each flight product relative to pure online alien products (y-axis) for consumers with the correct and wrong conception of codesharing (x-axis). Consumers that are well-informed about codesharing, on the left hand side of the diagrams, are willing to pay a virtually identical premium for codeshared flight products by Qantas and Air New Zealand (dashed lines) as the wrongly-informed consumers on the right hand side of the diagram. Thus, our data do not support the hypothesis that the increase in willingnessto-pay for virtually codeshared alien flights are caused by codeshare misconceptions.

\footnotetext{
${ }^{25}$ Here we only show the estimates of the parameters in the discrete choice component of the hybrid panel mixed logit model. The parameter estimates for the measurement and structural components are provided in Appendix C.

${ }^{26}$ Comparing the total log likelihood of the hybrid panel mixed logit models to that of the panel mixed logit models is otherwise not informative, as the models are not estimated on the same data (i.e., the panel mixed logit is estimated on the choice observations only, while the hybrid panel mixed logit is estimate on both the choice observations and risk indicators).
} 
Figure 3: Willingness-to-pay for carriers by codeshare (mis)conception
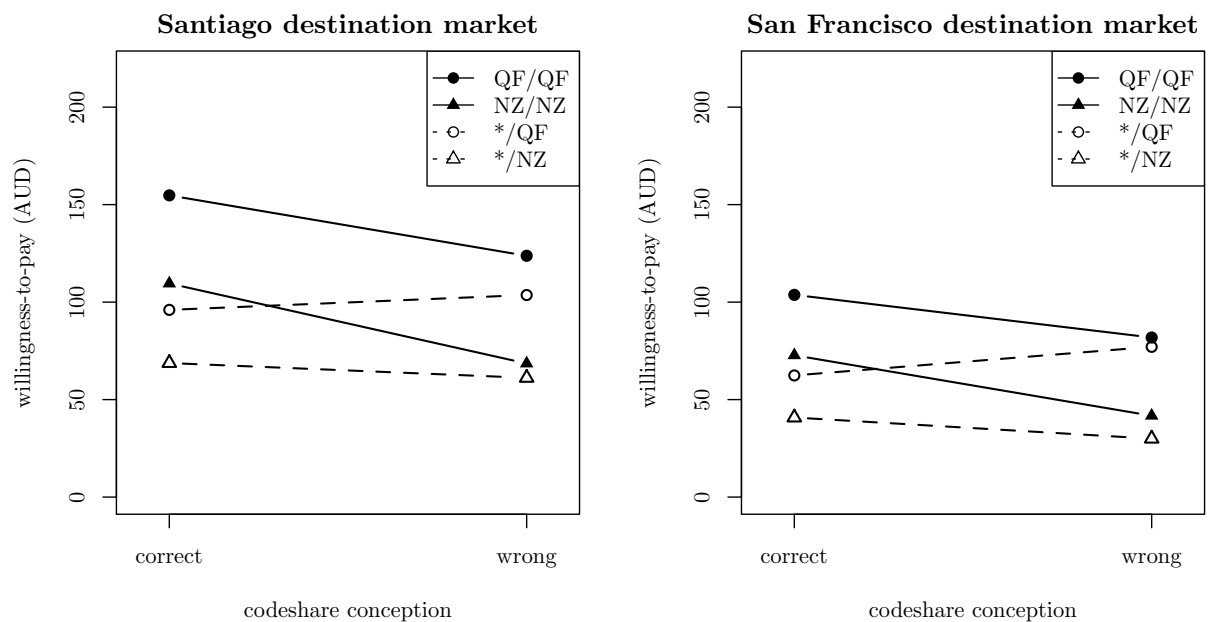

At the same time, Figure 3 illustrates that the premium for pure online products by Qantas and Air New Zealand (solid lines) is strictly higher for the well-informed consumers. It seems unlikely that this higher willingness-to-pay for pure online products by Qantas or Air New Zealand over pure online alien products, is the causal effect of having the correct conception of codesharing: neither of these product types involve codesharing. Rather, this pattern suggests that consumers who have a strong preference for flying with a specific carrier (e.g., their own national carrier) might have a stronger incentive to be informed of the true meaning of codesharing. ${ }^{27}$

The estimates of the risk attitude parameters in columns (1) and (3) of Table 6, represent the change in the premium for each product type over pure online products by alien carriers, for a one standard deviation increase in (latent) risk attitude. In the Santiago destination market, such a one standard deviation increase in risk attitude leads to a significantly higher premium for pure online flights by Qantas (26 AUD) and Air New Zealand (18 AUD), as well as alien flights codeshared by Qantas (19 AUD). Although the signs on these parameters are similar in the San Francisco destination market, the parameters are only significant for the pure online products (16 AUD for pure online products by Qantas; and 10 AUD for pure online products by Air New Zealand).

These effects are illustrated in Figure 4, which plots the willingness-to-pay for each flight product relative to pure online alien products (y-axis) over the range of risk attitude (x-axis). As shown

\footnotetext{
${ }^{27}$ The importance of the causal direction is not without practical consequence for carriers. They should not hope or expect that by better informing travelers of the true meaning of codesharing, the willingness-to-pay for their pure online flights compared to alien pure online flights increases.
} 
Figure 4: Willingness-to-pay for carriers by risk-aversion
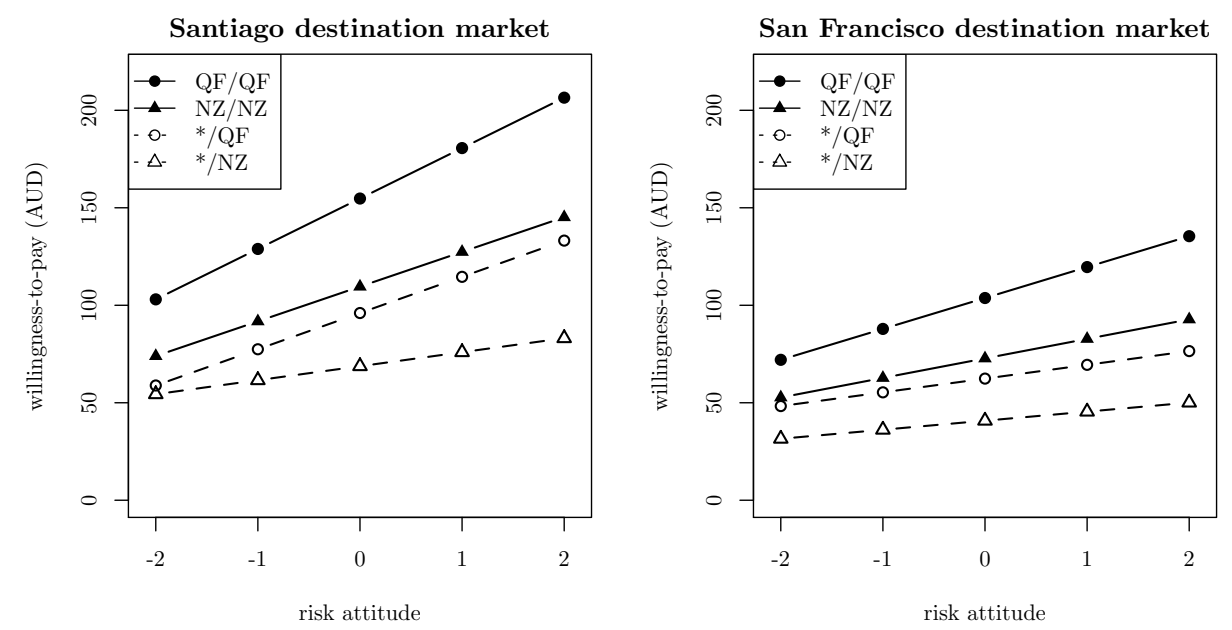

by the positive slopes for the pure online products (solid lines), more risk-averse consumers tend to avoid flying with alien carriers. Consistent with codesharing as a signaling phenomenon, the slopes associated with the virtual codeshare products (dashed lines) are also positive, although only significantly so for codesharing by Qantas in the Santiago destination market. Thus, these diagrams do provide evidence for the signaling explanation of the codesharing premium, although it only seems to apply to codesharing by the own national carrier and in markets where consumers are presumably more uncertain about the quality of alien carriers.

The estimates of the non-linear impact of risk attitude reported in column (2) and (4) of Table 6 and illustrated in Figure 5. They provide additional insights into the impact of risk attitude on the valuation of each flight product. As revealed by the highly convex line associated with the codeshare product of Qantas in the San Francisco destination market, codesharing does seem to exhibit a signaling effect in less familiar markets as well, although strictly for those consumers that are highly risk-averse. Moreover, as shown by the concave lines of all product types offered by Air New Zealand, highly risk-averse consumers tend to also avoid flight products of Air New Zealand in addition to those of alien carriers. ${ }^{28}$

Overall, our findings regarding risk attitude are consistent with the story that at least some consumers are willing to pay high premiums to their own national carrier to avoid uncertainty and risks that they perceive with alien carriers. Importantly, this risk premium also applies to alien flights

\footnotetext{
${ }^{28}$ However, while both destination markets show a concave line, concavity is only statistically significant in the Santiago destination market.
} 
Figure 5: Willingness-to-pay for carriers by risk-aversion (non-linear)
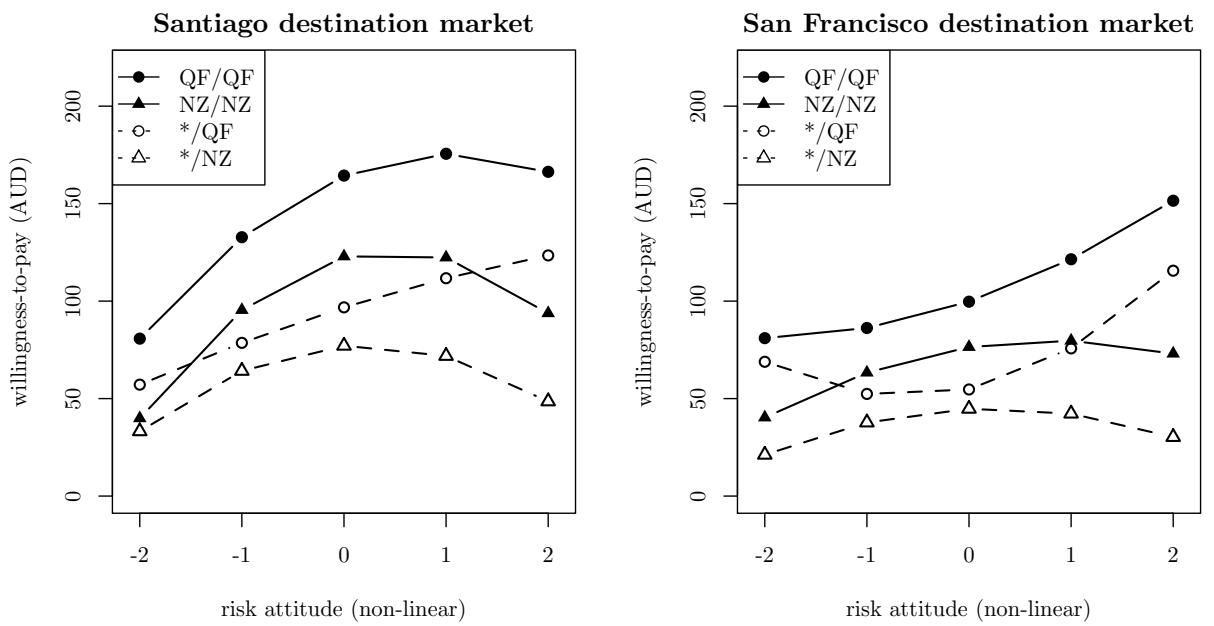

that are codeshared by the own national carrier, which suggests that consumers regard codesharing by their own national carrier as a signal of their home carrier's confidence in the product quality of that alien carrier with whom the consumer may not yet have any experience.

Finally, to ensure the robustness of our findings regarding codeshare misconceptions and risk attitude, we estimated a number of alternative specifications that: (1) include additional covariates, (2) allow for taste correlation and (3) include random cost parameters. The estimation results for these robustness checks are provided in Appendix C. Overall, the estimation results show that our findings are robust with respect to these more flexible specifications.

\section{Conclusion}

Over the last decades, connections between companies in geographically separate and culturally different countries intensified. This does not mean that consumers regard products from all countries as similar; consumers perceive some countries - often including their home country - as being superior and may be willing to pay a premium for products from these countries, whereas they may devalue products from countries they perceive less positively. Our results, based on virtual codesharing partnerships in aviation, show that similar effects arise when companies partner up with a company from a country that is valued highly by consumers.

Our analysis focuses on consumer willingness-to-pay for pure online and virtual codeshare flight products in international air transport markets. Our main result indicates that consumer valuation 
of flights by alien foreign carriers increases significantly once these flights are offered as codeshare products by consumers' own national carrier. The same holds, but to a lesser extent, for alien flights that are codeshared by a neighboring national carrier. These premiums occur for virtual codeshare products offered on non-stop routes where codesharing does not lead to quality improvements; that is, exactly the same service is offered. Moreover, the premiums are shown not to be related to frequent flier programs. This sets our findings apart from the increases in willingness-to-pay due to advantages of traditional codesharing as studied in the extant literature, including, improvements in connecting services and new opportunities to earn and redeem frequent flier miles.

We evaluated two alternative explanations of the willingness to pay a premium for virtual codesharing: unawareness of the meaning of codesharing, and consumer risk-aversion. We find no support for the common belief that unawareness among consumers about the meaning of codesharing leads to higher willingness-to-pay for codeshare products. If anything, the evidence suggests a reverse relationship: consumers with a strong preference for a specific carrier (e.g., the own national carrier) are more likely to be aware of the meaning of codesharing. We do, however, find that the willingness-to-pay for codesharing is especially pronounced for more risk-averse consumers and in less familiar route markets. These findings are consistent with the idea that consumers perceive codesharing by the domestic carrier as a quality signal on a carrier that is alien to them. This, in turn, raises willingness-to-pay for flights operated by that alien carrier.

Interestingly, our findings in an international context are in contrast to those established in the US domestic market, where consumers do not perceive a distinction between pure online and codeshared flights by the same carrier. However, if unfamiliarity with alien carriers indeed is the main driver of the price premium, it is to be expected that the distinction between pure online and virtual codeshared flights disappears in domestic route markets where consumers can evaluate the characteristics of the available carriers with more certainty. This assessment is corroborated by the highest willingness-to-pay for codeshared products occurring in the South-American destination market, which is the least familiar and most culturally different destination market studied in our study. In this light, it would be interesting if further research could generalize our findings to an array of international route markets that have more variation in terms of cultural, institutional and political distances.

Although our study focuses on virtual codesharing in the airline industry because this allows us to perfectly isolate the impact of partnerships from real product quality attributes, the insights are likely to carry over to other markets and other forms of horizontal partnerships (e.g., traditional 
codesharing, global airline alliances). While international partnerships are known to bring a host of other advantages to the involved firms, the signaling mechanism assessed in our study constitutes a novel, additive benefit that seems especially relevant in international contexts where consumers are uncertain about the quality of foreign providers. 


\section{References}

Adler, N. and Hanany, E. (2016). Regulating inter-firm agreements: The case of airline codesharing in parallel networks. Transportation Research Part B: Methodological, 84:31-54.

Armantier, O. and Richard, O. (2008). Domestic airline alliances and consumer welfare. The RAND Journal of Economics, 39(3):875-904.

Ashok, K., Dillon, W. R., and Yuan, S. (2002). Extending Discrete Choice Models to Incorporate Attitudinal and Other Latent Variables. Journal of Marketing Research, 39(1):31-46.

Australian Bureau of Infrastructure Transport and Regional Economics (2018). International Airlines Operated Flights and Seats.

https://bitre.gov.au/publications/ongoing/international_airlines-operated_flights_seats.aspx.

Australian Bureau of Statistics (2018). 2016 Census Community Profiles. http://www.abs.gov.au/.

Ben-Akiva, M., Mcfadden, D., Train, K., Walker, J., Bhat, C., Bierlaire, M., Bolduc, D., Boersch-Supan, A., Brownstone, D., Bunch, D. S., Daly, A., De Palma, A., Gopinath, D., Karlstrom, A., and Munizaga, M. A. (2002). Hybrid Choice Models: Progress and Challenges. Marketing Letters, 13(3):163-175.

Bhat, C. R. and Dubey, S. K. (2014). A new estimation approach to integrate latent psychological constructs in choice modeling. Transportation Research Part B: Methodological, 67:68-85.

Bierlaire, M. (2016a). Estimating choice models with latent variables with PythonBiogeme. Report transp-or 160628, series on biogeme, Transport and Mobility Laboratory, School of Architecture, Civil and Environmental Engineering, Ecole Polytechnique Fédérale de Lausanne, Switzerland.

Bierlaire, M. (2016b). PythonBiogeme: a short introduction. Report transp-or 160706, series on biogeme, Transport and Mobility Laboratory, School of Architecture, Civil and Environmental Engineering, Ecole Polytechnique Fédérale de Lausanne, Switzerland.

Bilotkach, V. and Huschelrath, K. (2011). Antitrust immunity for airline alliances. Journal of Competition Law and Economics, 7(2):335-380.

Brueckner, J. K. (2001). The economics of international codesharing: an analysis of airline alliances. International Journal of Industrial Organization, 19(10):1475-1498. 
Brueckner, J. K. (2003). International Airfares in the Age of Alliances: The Effects of Codesharing and Antitrust Immunity. Review of Economics and Statistics, 85(1):105-118.

Brueckner, J. K., Lee, D. N., and Singer, E. S. (2011). Alliances, codesharing, antitrust immunity, and international airfares: Do previous patterns persist? Journal of Competition Law and Economics, 7(3):573-602.

Choi, J. P. and Jeon, D.-S. (2007). A Leverage Theory of Reputation Building with Co-Branding: Complementarity in Reputation Building. SSRN Electronic Journal.

Choi, J. P. and Peitz, M. (2018). You are judged by the company you keep: Reputation leverage in vertically related markets. International Journal of Industrial Organization, 61:351-379.

Chrzan, K. and Orme, B. (2000). An overview and comparison of design strategies for choice-based conjoint analysis. Technical report.

Cosar, A. K., Grieco, P. L., Li, S., and Tintelnot, F. (2018). What drives home market advantage? Journal of International Economics, 110:135-150.

Czajkowski, M., Vossler, C. A., Budziński, W., Wiśniewska, A., and Zawojska, E. (2017).

Addressing empirical challenges related to the incentive compatibility of stated preferences methods. Journal of Economic Behavior and Organization, 142:47-63.

de Jong, G., Behrens, C., and van Ommeren, J. (2019). Airline loyalty (programs) across borders: A geographic discontinuity approach. International Journal of Industrial Organization, $62: 251-272$.

Dohmen, T., Falk, A., Huffman, D., Sunde, U., Schupp, J., and Wagner, G. G. (2011). Individual risk attitudes: measure, determinants, and behavioral consequences. Journal of the European Economic Association, 9(3):522-550.

Gayle, P. G. (2007). Is virtual codesharing a market segmenting mechanism employed by airlines? Economics Letters, 95(1):17-24.

Gayle, P. G. and Thomas, T. (2016). Assessing firm behavior in carve-out markets: Evidence on the impact of carve-out policy. Journal of Economic Behavior and Organization, 128:178-194. 
Gayle, P. G. and Xie, X. (2019). Firms' markup, cost, and price changes when policymakers permit collusion: Does antitrust immunity matter? Journal of Economic Behavior and Organization, 157:680-707.

Giannetti, M. and Yafeh, Y. (2012). Do cultural differences between contracting parties matter? Evidence from syndicated bank loans. Management Science, 58(2):365-383.

Goh, K. and Uncles, M. (2003). The benefits of airline global alliances: an empirical assessment of the perceptions of business travelers. Transportation Research Part A: Policy and Practice, $37(6): 479-497$.

Hess, S. and Train, K. (2017). Correlation and scale in mixed logit models. Journal of Choice Modelling, 23:1-8.

Hess, S., Train, K., and Polak, J. W. (2006). On the use of a Modified Latin Hypercube Sampling (MLHS) method in the estimation of a Mixed Logit Model for vehicle choice. Transportation Research Part B: Methodological, 40(2):147-163.

Ito, H. and Lee, D. (2007). Domestic Code Sharing, Alliances, and Airfares in the U.S. Airline Industry. The Journal of Law and Economics, 50(2):355-380.

Johnson, J. P. (2013). Who Posts the Reputational Bond? Advertising and Cobranding in Vertical Relationships. The Journal of Industrial Economics, 61(1):28-61.

Liu, Q. and Tang, Y. E. (2015). Construction of Heterogeneous Conjoint Choice Designs: A New Approach. Marketing Science, 34(3):346-366.

Mantin, B. and Rubin, E. (2016). Fare prediction websites and transaction prices: Empirical evidence from the airline industry. Marketing Science, 35(4):640-655.

McFadden, D. (1974). Conditional logit analysis of qualitative choice behavior. In Zarembka, P., editor, Frontiers in Econometrics, pages 105-142. Academic Press, New York.

Rao, A. and Ruekert, R. W. (1994). Brand alliances as signals of product quality. Sloan management review, 36(1):87-97.

Rao, A. R., Qu, L., and Ruekert, R. W. (1999). Signaling Unobservable Product Quality through a Brand Ally. Journal of Marketing Research, 36(2):258-268. 
Raveau, S., Ortúzar, J. d. D., and Yáñez, M. F. (2012). Practical and empirical identifiability of hybrid discrete choice models. Transportation Research Part B: Methodological, 46(10):1374-1383.

Sándor, Z. and Wedel, M. (2005). Heterogeneous conjoint choice designs. Journal of Marketing Research, 42(2):210-218.

Simonin, B. L. and Ruth, J. A. (1998). Is a Company Known by the Company it Keeps? Assessing the Spillover Effects of Brand Alliances on Consumer Brand Attitudes. Journal of Marketing Research, 35(1):30-42.

Train, K. (2009). Discrete Choice Models with Simulation. Cambridge University Press, Cambridge.

Train, K. and Weeks, M. (2005). Discrete Choice Models in Preference Space and Willingness-to-Pay Space. In Scarpa, R. and Alberini, A., editors, Applications of Simulation Methods in Environmental and Resource Economics, pages 1-16. Springer-Verlag, Berlin/Heidelberg.

van der Lans, R., Van den Bergh, B., and Dieleman, E. (2014). Partner selection in brand alliances: An empirical investigation of the drivers of brand fit. Marketing Science, 33(4):551-566.

Verlegh, P. W. J. and Steenkamp, J.-B. E. M. (1999). A review and meta-analysis of country-of-origin research. Journal of Economic Psychology, 20(5):521-546.

Vij, A. and Walker, J. L. (2016). How, when and why integrated choice and latent variable models are latently useful. Transportation Research Part B: Methodological, 90:192-217. 
A Example of stated preference choice task

Figure 6: Example of stated preference choice task

Sydney Airport (SYD) - San Francisco International Airport (SFO)

You are going on a trip from Sydney Airport (SYD) to San Francisco International Airport (SFO) and you are looking for a flight. On a travel website you find the following four options. Which flight would you choose?

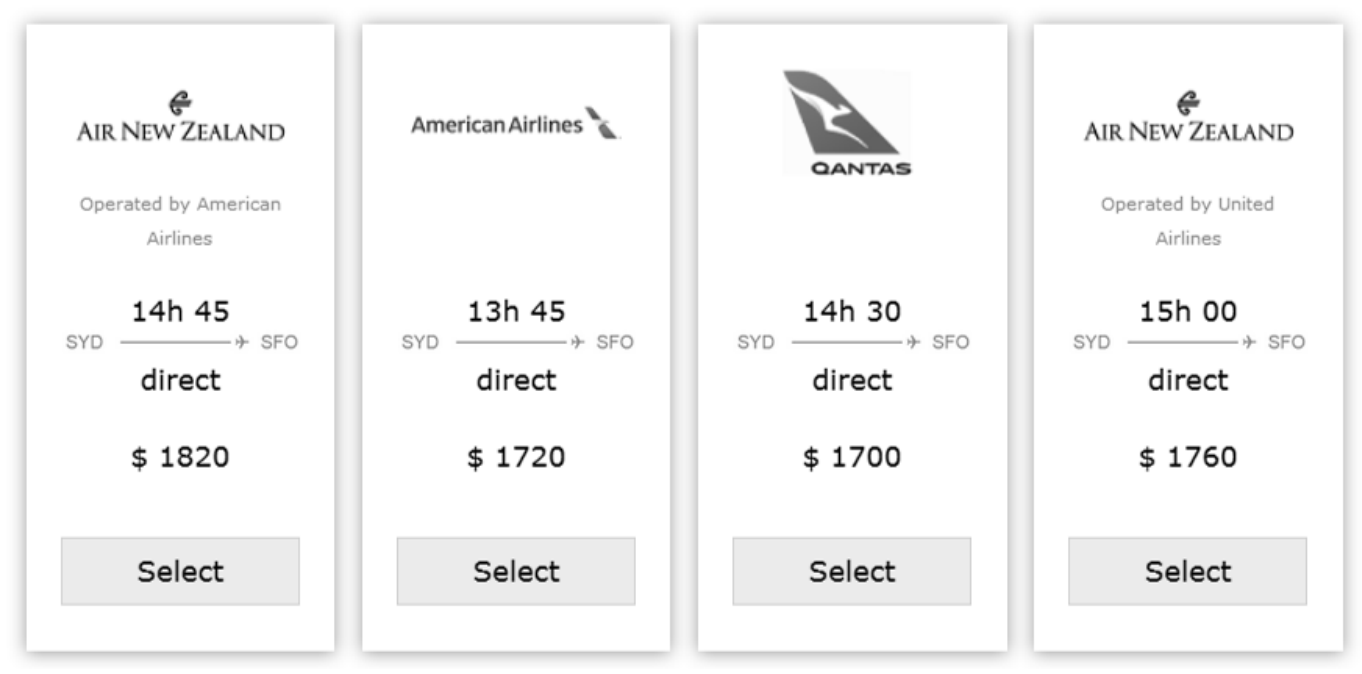

B Correlation matrix risk indicators

Table 7: Correlation matrix risk indicators

\begin{tabular}{lcccc}
\hline \hline & general risk & financial risk & health/safety risk & recreational risk \\
\hline general risk & 1 & & & \\
financial risk & 0.715 & 1 & 1 & \\
health/safety risk & 0.628 & 0.574 & 0.653 & 1 \\
recreational risk & 0.772 & 0.653 & & \\
\hline
\end{tabular}




\section{Supplementary estimation results}

Table 8: Measurement and structural models estimation results

\begin{tabular}{|c|c|c|c|c|}
\hline \multirow[b]{2}{*}{ Parameters } & \multicolumn{2}{|c|}{$\begin{array}{c}\text { Santiago } \\
\text { destination market }\end{array}$} & \multicolumn{2}{|c|}{$\begin{array}{c}\text { San Francisco } \\
\text { destination market }\end{array}$} \\
\hline & \multicolumn{2}{|c|}{ (1) } & \multicolumn{2}{|c|}{ (2) } \\
\hline \multicolumn{5}{|l|}{ Structural parameters: } \\
\hline Gender & $0.34^{* *}$ & $(0.09)$ & $0.26^{* *}$ & $(0.10)$ \\
\hline Age & $0.01^{* *}$ & $(0.00)$ & $0.01^{*}$ & $(0.00)$ \\
\hline University degree & $-0.32^{* *}$ & $(0.09)$ & $-0.29^{* *}$ & $(0.10)$ \\
\hline Employed & $-0.32^{* *}$ & $(0.11)$ & $-0.39^{* *}$ & $(0.12)$ \\
\hline Student & $-0.68^{* *}$ & $(0.25)$ & $-0.79^{* *}$ & $(0.24)$ \\
\hline \multicolumn{5}{|l|}{ Measurement parameters: } \\
\hline General risk attitude constant & $5.62^{* *}$ & $(0.23)$ & $5.82^{* *}$ & $(0.25)$ \\
\hline General risk attitude latent variable & $2.16^{* *}$ & $(0.08)$ & $2.17^{* *}$ & $(0.09)$ \\
\hline General risk attitude scale & $1.15^{* *}$ & $(0.06)$ & $1.17^{* *}$ & $(0.06)$ \\
\hline Financial risk attitude constant & $6.37^{* *}$ & $(0.21)$ & $6.55^{* *}$ & $(0.23)$ \\
\hline Financial risk attitude latent variable & $1.95^{* *}$ & $(0.09)$ & $1.96^{* *}$ & $(0.10)$ \\
\hline Financial risk attitude scale & $1.62^{* *}$ & $(0.06)$ & $1.63^{* *}$ & $(0.06)$ \\
\hline Health/safety risk attitude constant & $7.08^{* *}$ & $(0.20)$ & $7.25^{* *}$ & $(0.22)$ \\
\hline Health/safety risk attitude latent variable & $1.79^{* *}$ & $(0.10)$ & $1.80^{* *}$ & $(0.10)$ \\
\hline Health/safety risk attitude scale & $1.76^{* *}$ & $(0.06)$ & $1.77^{* *}$ & $(0.06)$ \\
\hline Recreational risk attitude constant & $5.91^{* *}$ & $(0.23)$ & $6.13^{* *}$ & $(0.26)$ \\
\hline Recreational risk attitude latent variable & $2.21^{* *}$ & $(0.09)$ & $2.24^{* *}$ & $(0.10)$ \\
\hline Recreational risk attitude & $1.37^{* *}$ & $(0.06)$ & $1.34^{* *}$ & $(0.06)$ \\
\hline Observations (indicators) & \multicolumn{2}{|c|}{2008} & \multicolumn{2}{|c|}{2008} \\
\hline Individuals & \multicolumn{2}{|c|}{502} & \multicolumn{2}{|c|}{502} \\
\hline Log likelihood (joint model) & \multicolumn{2}{|c|}{-6824.158} & \multicolumn{2}{|c|}{-6949.672} \\
\hline
\end{tabular}

Note(s): All models are estimated using BIOGEME (Bierlaire, 2016b). These measurement and structural parameter estimates correspond to those obtained from the baseline hybrid panel mixed logit specification of column (1) and (3) in Table 6. ${ }^{*} \mathrm{p}<0.05 ;{ }^{* *} \mathrm{p}<0.01$ 


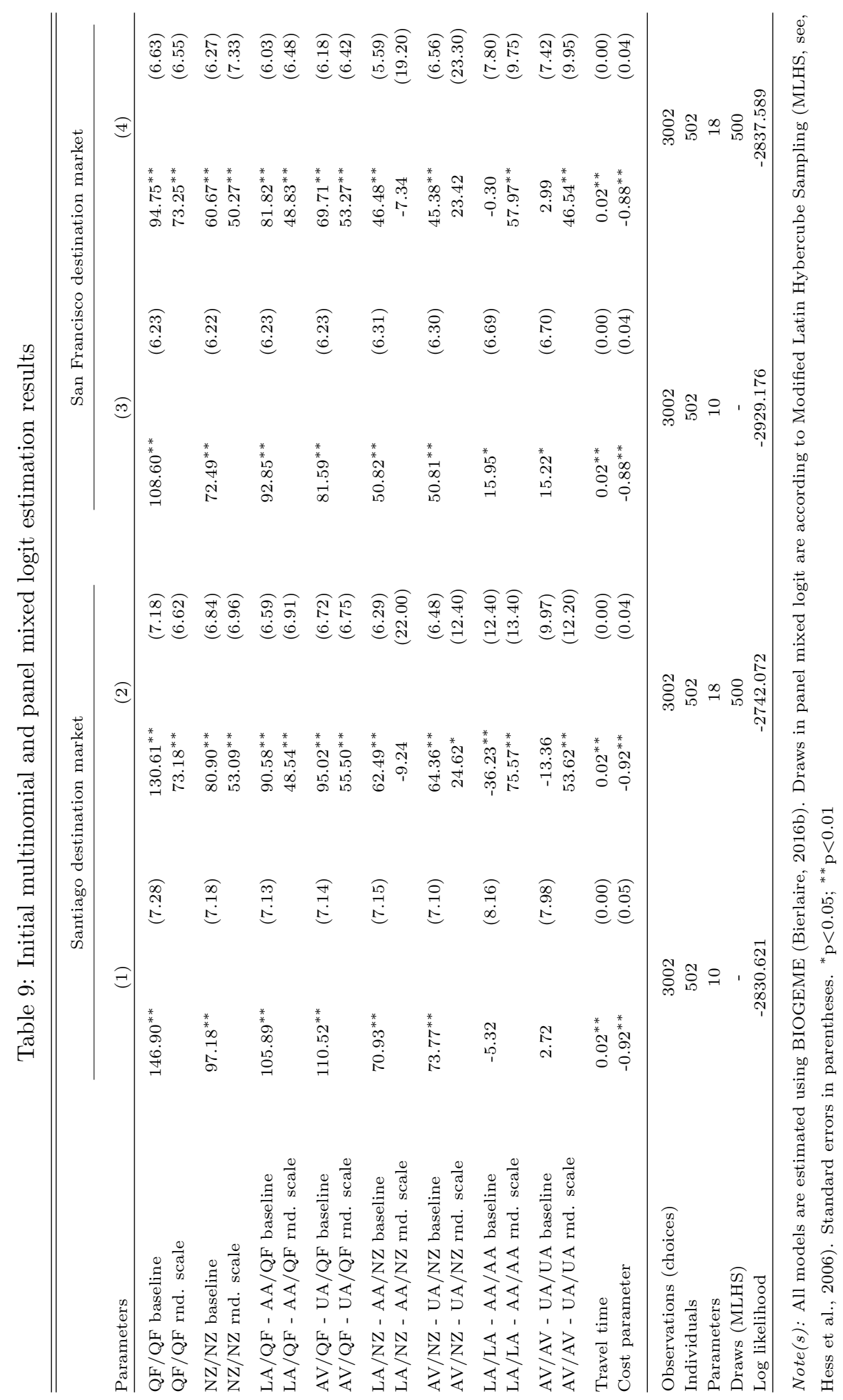




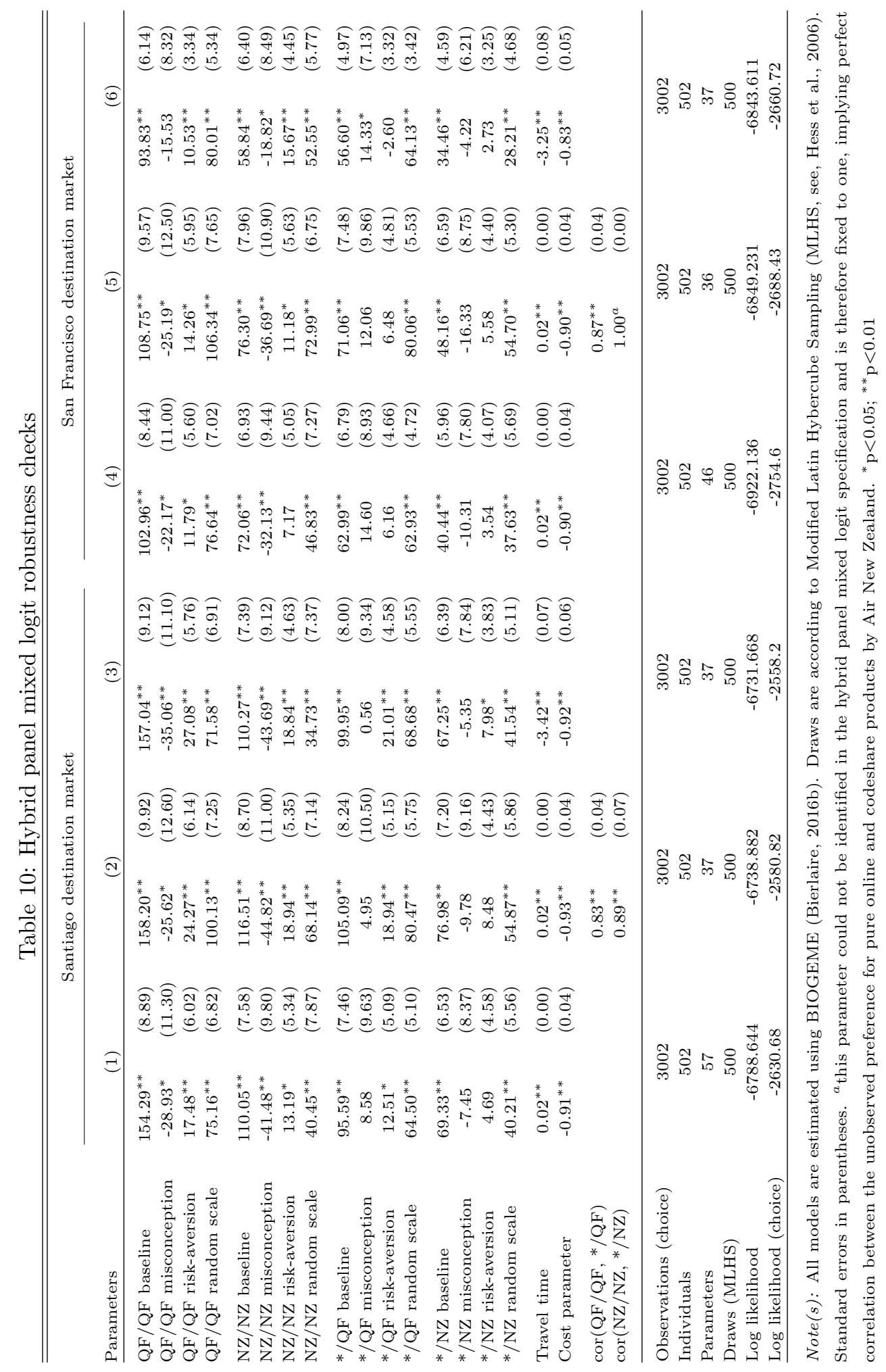

